\title{
A Geopolitical and Geovisualization Challenge: Increasing the Awareness of Global Environmental Change through Postage Stamp Issues
}

\author{
Stanley D. Brunn \\ Department of Geography, University of Kentucky, Lexington, KY, USA \\ Email: stan.brunn@uky.edu
}

How to cite this paper: Brunn, S.D. (2017) A Geopolitical and Geovisualization Challenge: Increasing the Awareness of Global Environmental Change through Postage Stamp Issues. Natural Resources, 8, 130158.

https://doi.org/10.4236/nr.2017.83010

Received: February 12, 2017

Accepted: March 28, 2017

Published: March 31, 2017

Copyright $\odot 2017$ by author and Scientific Research Publishing Inc. This work is licensed under the Creative Commons Attribution International License (CC BY 4.0).

http://creativecommons.org/licenses/by/4.0/

\begin{abstract}
Global environmental change is one of the major distinguishing features associated with the contemporary world political map. It is significant not only because it illustrates the intersections between geopolitics and environmental change, but also because identifying the major environmental features and solving existing and future problems are primarily political in nature. Key features of global environmental change include global warming impacts on the poleward shifts in biodiversity and agricultural patterns, rising sea levels and human adjustments, changing coastal habitats, and promoting increased environmental awareness especially in urban clusters, where most people live. In the contemporary geopolitical and environmental world, visualization is a key feature not only used to inform both planetary inhabitants, environmental organizations and governments, but also serves as an effective policy, that is, to "show" or demonstrate effective changes and the need for action. States are key institutions in this thinking as they can both inform and address the impacts of global environmental change through various images: maps, earthbased photographs, satellite coverage, websites and educational venues including curriculum content and stamps. Visual geopolitics is already recognized as being an important source influencing public opinion, as evidenced in the attractive visible layouts, graphics, colors, often "seductive" designing of official websites. Postage stamps is an additional important and "informing" visible way that states inform both insiders and outsiders about how they "see" their place in the world. They also provide a view into how a state sees its "own" place in the world of environmental change and how it sees "the world beyond its own borders". I introduce the concept of "visual geopolitics" and use recent postage stamp issues about global environmental change from a number of countries to illustrate how they are informing views of their own
\end{abstract}


and the world about pressing environmental issues.

\section{Keywords}

Global Environmental Change, Environmental Awareness, Geovisualization, Geopolitics, Postage Stamps, Planetary Futures

\section{Introduction}

Without question, environmental issues have reached front and center stage in the contemporary information world. This observation is evident in regular reports in the visual and print media about atypical or unexpected environmental disasters, including prolonged droughts, more frequent and dangerous storms and hurricanes, policy debates, debates and treaties at national, transnational and international levels, and increased attention to environmental issues by familiar and new scholarly communities. In the scholarly world new fields of interdisciplinary and cross-disciplinary study are readily apparent in increased numbers of regional and international conferences, new journals and new college/university degree programs. These developments are evident in new fields of study such as sustainability, climate change, hazard mitigation, and the geopolitics of environmental change. While traditional disciplines such as biology, agriculture, geology, economics, meteorology, human and physical geography have long traditions of studying the human/environmental worlds, it is new scholarly communities that have fully engaged junior and senior scholars entering these discussions and making valuable contributions. The new and "intersecting" or overlapping scholarly communities include those with interests in environmental psychology and politics, green energy technology, sustainable architecture, environmental humanities, heritage conservation and visual reporting. New terminology, concepts, theories, and paradigms not only appear in the scholarly and public arenas, but also in the education of children and adults and in the re-education of wider public communities. Entire cohorts, old and new, are being exposed to the importance of being more aware of such transnational issues as global warming, shrinking biodiversity, depleted agricultural, energy and industrial resource bases, water quality and availability, and regional and global health care crises.

Recognizing the importance of existing and the rapidly unfolding of new and unexpected developments in the study of human/environmental conditions, this paper presents and discusses these regional and global issues in a new context. That context is one that not only highlights the importance of states or countries of the world in addressing these issues and informing their publics both about their own environmental situations and futures, but also extending that worldview to include international spheres. The focus in this discussion is on visualization, or more specifically, how countries are seeking ways to inform their citizens through the issuing of postage stamps about global environmental changes. 
Visual geopolitics, as discussed below, is an example of two important and effective ways (the visual and political) that states can not only inform their publics, but also increase their citizens' knowledge about local and global environmental changes that are occurring.

This paper has four major objectives. First is to examine the importance of looking at the connections or intersections between the various scholarly fields and disciplines that are concerned with global environmental changes. Specifically, these are the natural sciences, the social sciences and humanities. Second is to focus on the "geopolitics of visualization", a concept that reflects the increased importance of exploring the visual production, reproduction and representation of materials that relate to increased environmental awareness on a global scale. Third is to address how states, which are the major actors or players in the global environmental arena, are responding to these challenges, specifically about how best and most effectively they can generate environmental messages to their populations and others about what they are thinking and doing. Fourth, and final, is to address specifically how states promote their awareness through postage stamps with a focus on two major environmental themes: global warming and climate change. A point made below is that stamps are visual products of states that reveal what the state wishes its own residents and others to know about what it is doing. I discuss this last point by illustrating some of the themes from the more than eighty countries that have such stamp issues.

In the following sections I first present the conceptual and theoretical framework of these topics in greater detail. Then I selectively introduce some related literature regarding the geopolitics and visualization interfaces and discuss selected examples of how geographers and others have used stamps to illustrate a given state's economic and political program and how stamps can be used to measure transitions occurring within states themselves. Then I present the methodology and data sets used to discuss how states are using stamps with environmental themes, in this case global warming and climate change, to promote environmental awareness. I conclude by suggesting additional research paths for those interested in these geopolitical, visualizational and environmental awareness intersections.

\section{Conceptual and Theoretical Framework}

\subsection{Physical and Human Science: Intersections}

If we examine the disciplines that study environmental issues and change we can conveniently divide them into the natural sciences as one group and the social sciences and humanities as another. The natural sciences would include biology, oceanography and meteorology, hydrology, geology and earth science geography. These are the standard disciplines that study earth science processes and patterns. Each has, as we know, a long history of studying topics that are within the prevue of those studying environmental topics such as global warming, air and water pollution, coral reef destruction, desertification, shrinking biodiversity patterns and deforestation. The social sciences have been more recent contribu- 
tors to environmental issues. Human geography, as one example, has a longer tradition of studying nature/society interfaces, including land use changes, water, air and land pollution, mining, industrial pollution, water quality, human health conditions than have anthropology, sociology, economics and political science. These "newcomers" to the environmental science fields have made rapid strides in the past few decades in looking at human/environmental linkages, human rights, land tenure, indigenous knowledge, tourism, architecture, public policy and legal issues. The humanities have also been, relatively speaking, "latecomers" to studying environmental awareness and conditions. But they, like some social sciences, have also begun to focus on issues about human well-being, human rights, and environmental traditions and conditions in history, literature, religion, poetry, film, language, music, drama and art. In many countries where environmental sciences have a long history and in countries where the scholarly environmental history is much shorter, professionals look at global warming, environmental pollution, sustainability, energy, human rights and law, and other emerging fields that cross the traditional subject matter categories mentioned above.

\subsection{The Geopolitics of Visualization}

When discussing the disciplinary and interdisciplinary intersections, a key player is the state or the central government of any country. States are responsible for governing the peoples, places and environments within their borders. But they are also responsible for much of the information that is made available to and consumed by their public. This may be information about environmental conditions, but also about what is taught in schools, what is reported by state media, and what is provided with state funding, that is, museums, festivals, holiday events and various other cultural events. All these spheres of public knowing have information or knowledge production at their base [1]. Information is considered a key feature of state policy these days; it is more important than coal or steel production, agricultural output or even the size of the armed forces and military weaponry. Political geographers, political scientists and media producers are aware of the growing role of information in society and government; these include security networks, internet capabilities, social media, and the growing importance of visual technologies, including those related to the World Wide Web, Google images and mapping, official photographs, official visual reporting of local and global events, and, I would add, even stamp issues [2]-[11]. These developments comprise what some social scientists term the "geopolitics of information" or as we will discuss in this paper the "geopolitics of visualization".

Against this background we can easily understand why such terms as environmental awareness, environmental quality, environmental welfare, environmental legislation and environmental education are all phrases that relate to a "visual or observant" world. They are evident in much of what the public sees, hears or discusses about policies, legislation, cultures and environmental quality 
and condition. The visual reporting and representation of information is at the surface, or slightly beneath the surface, of a series of environmental issues and topics that are in public eye's about not only existing conditions in cities and rural areas but in countries around the world. When one hears about disappearing ice caps and glaciers melting or expanding deserts or reductions in air or water pollution or the disappearance of plant and animal species on land and in oceans, one is likely to associate these with environmental subjects in some photograph or map one has seen. One is also likely to consider that identifying and solving the problems requires subject matter knowledge in more than one discipline or field. For example, disappearing plants and animals are not only important to marine, coastal or alpine biologists, but also to anthropologists, historical ecologists and environmental political scientists. Similarly, global warming is not solely the prevue these days of meteorologists and climatologists, but also economists, political scientists, geographers, and those in public health fields. What is important is to acknowledge that in looking at environmental conditions, issues, problems and solutions in today's world, we have to explore emerging intersecting fields such as sustainability and climate change. Inter- and cross-disciplinary scholarly communities are needed to explore underlying causes, but also realistic short and long term solutions.

\subsection{An Intersecting World}

The point just made is worth repeating. That is, the engaging and emerging scholarly worlds are increasingly looking for interrelationships or intersections in exploring issues related to environmental concerns, awareness and policies. It is an "intersecting" scholarly world where the areas of overlapping interest are more important than a single discipline subject matter "core" or "perspective" of a specific discipline in the natural sciences, social sciences and humanities (Figure 1).

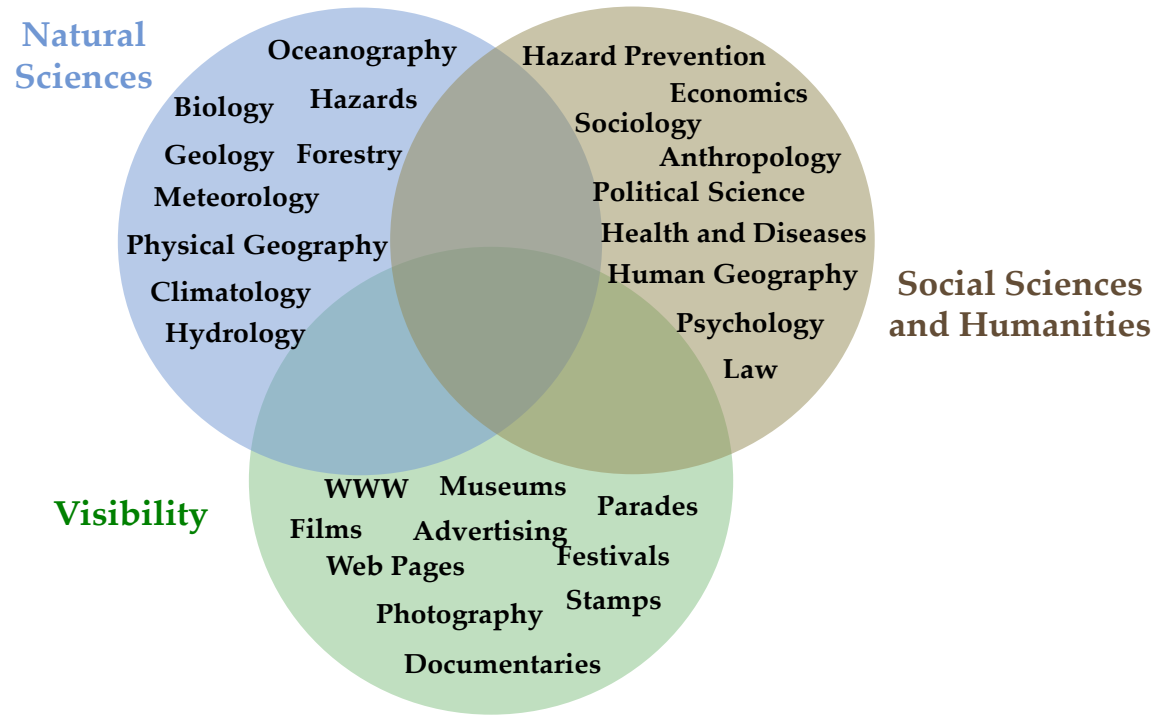

Figure 1. Conceptualizing the study of a state's global awareness of global warming and climate change. 
An example of how this "new" intersecting world is evident is the appearance of new scholarly journals that intersect emerging subject-matter fields. Since 2000 new journals have interdisciplinary, transdisciplinary and international editors and editorial boards with members in many counties in the Global North and Global South. Examples include: Sustainability, Natural Hazards and Earth System Science, Land, Anthropocene, Global Challenges, and Nature Ecology and Evolution. The number of online and open source journals in these and related fields has skyrocketed in the past decade with no end in sight.

One further dimension of environmental awareness in the scholarly world that merits mention is the visual presentation and representation of material. Many junior and senior scholars see the "visual world" as an emerging area of focus for the presentation of materials for multiple disciplinary and interdisciplinary audiences. The "visual" includes the increased use of maps, photographs, graphs and other graphics as integral parts of model building, descriptions and analyses. One can easily make the case that in the contemporary world the visual is more important than the text or narrative. That is, maps, photos, diagrams and graphs are replacing text or lengthy sections of text.(For those of us who teach, we know that many students much prefer to see a map or graph or photo rather than read a couple of pages of solid text.)Because of this increased "visualization," I also maintain that we need to instruct students and professionals with non-visual intellectual heritages in "how to read the visual," especially how to "read" maps. Maps are more than "showing," but also ways to analyze spatial processes and patterns.

The visuals are important in increasing one's awareness of environmental issues. It is not difficult to recognize the greater number of environmental photos and maps (world and national) in public policies and discourses now than even ten years ago. "Visual learning" is often front and center in public awareness. It is not simply reading about expanding deserts in North Africa or Central Asia or the U.S. Southwest that is important, but "seeing" on a map those areas of expanded deserts and accompanying ground-level and satellite images of rural and village economies affected by prolonged aridity and water deficits. The same holds true for places that have been affected by massive deforestation, including insular Indonesia and the Amazon Basin. Or examples of glaciers melting, ice caps shrinking and ice floes off Antarctica. Or maps of poverty, disease outbreaks and shifts in environmental public opinions in large urban areas. The maps depicting these environmental conditions are probably move important in increasing public opinion than government reports and conferences addressing these conditions. Likewise graphs that show increased $\mathrm{CO}_{2}$ levels due to fossil fuel use or graphs that show declines in biodiversity are considerably more effective ways to communicate issues about climate change, pollution levels and public health than dense paragraphs of text, detailed tables or even mathematical formulae.

\section{State Strategies to Increase Environmental Awareness}

A point that is often neglected in studying major societal problems, including 
environmental quality, public health, and social justice, is the role of the state. That is, governments-local and national or regional and international-are the major institutions that affect quality of life, living conditions, the legal structure of a society, and also the educational content of school curricula. Governments are one of the "institutional threads" that integrate life and well-being as well as the legal structure of any society. What a government does or does not do about pressing issues related to human rights, environmental quality, social justice and public involvement can be traced to its programs and policies. In short, "all of life is political," a truism that applies when looking at boundaries, human rights, representation and moral geography inquiries.

It is not difficult to view the state as the or a major player in public issues like education, transportation, housing, and land use planning. But the state (local or national) is also a major player when discussing public health initiatives, setting pollution levels, measuring quality of life indicators, establishing product safety levels, and ensuring worker and consumer protection levels. In the past several decades the state has also become the major institution collecting information on a wide variety of environmental conditions. These include measuring ozone levels, ensuring safe drinking water conditions, monitoring climate change, establishing safety levels for water, air, and noise pollution, developing consumer safety policies for homes, factories and businesses, setting emission levels for exhaust from polluting factories and motor vehicles and also establishing "green" energy and economic incentives for businesses and consumers. We have witnessed a change of venue as well, that is, where maps and images (satellite and ground level) have become more important than text in informing the public. In short, the state has become a major catalyst for increasing environmental awareness. And it has increased that awareness not only for itself, but working with other states within a larger region as well as at international levels. Global and regional conferences on environmental issues, once a rarity, are now a regular item on the political agenda of small and large states in the Global North and Global South. Sustainability, renewable energies and "green" education, environmental legislation and architecture are themes for current-day discussion and action.

Aside from the "information geopolitics" worlds discussed above, which is mostly about the Internet and the World Wide Web, the "geopolitical images of stamps" needs to be introduced and discussed. This literature explores the intersections of two related themes: visual geopolitics and postage stamp issues. There is a small but important literature on visual geopolitics that examines the intersections of geopolitics and visualization, especially the use of the Internet and World Wide Web and other search engines, such as Google, which have a strong visual component [2] [12].

Addressing environmental changes and future environmental worlds presents a challenge for political leaders because effective changes will not be seen immediately, but more likely twenty or fifty years or a century down the road. Rather than dealing with their next election, political leaders have to consider some an- 
ticipated and also some unexpected future changes and unintended consequences of what are currently enacted into laws or regulations. Proposing and enacting policies about land use changes that are the result of climate change or the losses of coastal areas, tourist/recreation areas, crop lands, lakes and rivers as well as plants and wildlife are among the many imponderables countries and cities in the Global North and South face. Compensating for property loss or compensating victims of local and regional climate change, for example, coastal regions, are among the legal, financial and social challenges facing local, regional and national governments. The international legal structures also face these issues, especially islands and island communities that will experience sea level rises, the relocation of climate refugees to safe havens, and financing efforts to halt drastic impacts of climate change. Monitoring these local, regional and international changes is more than measuring the impacts, but so are preparing and updating maps that show new boundaries for coastlines, croplands, and territorial seas.

\section{Relevant Literature}

This increased environmental awareness has included creative and effective ways to educate and inform citizens about pressing environmental issues at local levels and also at global levels. The state can accomplish these goals through a variety of venues, including preparing materials for schools at all levels, primary through university, and sponsoring conferences of political leaders and conferences for scholars from different disciplines. There is also an increasingly strong visual component or feature to states promoting their missions to their own citizens and to those from beyond its borders. Here I am referring to the visual production, reproduction and dissemination of information, especially about environmental and environmentally-related topics, through official film documentaries, official websites and linkages to websites, festivals, museum displays, drama and sporting events and, I would add, stamps [13] [14] [15] [16]. Semiotics or the study of signs and representation is an integral part of this information-based research tradition. As noted above, these visual innovations are becoming increasingly important in a world that is used to television reporting visual news, news specials about some important historical or contemporary event, Google Earth maps, Internet access to visual information sources, and computer games and programs for those with keen visual interests and instincts. These visual sources are important in the information one gains about global news, sports, music, travel and consumer products from a computer in a home or office or also using an iPhone with apps as well as Facebook, Twitter and other social media communication devices.

Behind all of these developments, whether these relate to information that is produced or what is reproduced, manipulated and disseminated, is the state. The state, as noted above, is emerging as the major source of visual information. The concept "visual geopolitics" aptly describes this emergence of the visual into the politics of "everything", including environmental awareness. We also observe 
the "visual geopolitics" concept also in photographs of heads of state attending an international conference, some notable historical, cultural or economic event such as the opening of a new bridge, the welcoming session of new citizens or those attending an international trade fair or sporting event or the signing of treaties related to trade, the reduction of greenhouse bases or opening a new national park.

\section{Stamps as Vehicles to Increase Environmental Awareness}

Stamps are products of the state and have been described by scholars as "paper ambassadors of state" [17], "the smallest icons of popular culture" [18] and "small visual pieces of diplomacy" [19] [20]. Postage stamps are above all state products, just like the production of toys, cars, computer parts, clothing or food products. They are considered elements of a state's iconography or visible images, much like flags, images, monuments and historical landmarks [19] [20] [21] [22]. Official photographs, television advertisements, official web pages, official photographs and bank notes are additional visible ways that states promote themselves to those inside and beyond their borders. These are ways the states brand themselves for promotional purposes [23] [24] [25].

The relevant literature on stamps is also not voluminous, but the extant literature looks at stamp issues and stamp issuing policies for historical and contemporary countries on the world political map. Many of the earliest articles on postage stamps described the subjects of the stamp issues. More recently scholars from different fields have looked critically at specific themes, such as the first issues of new states on the world political map, stamps about specific subjects such as religion, music, tourism, etc., reading a country's history through its stamp issues, historical inquiries into a country's stamp policies and more recently how stamp issues can be used to examine political transitions within countries. A major theme in much of the recent research is that stamps, as visual products, can be viewed as information products (or even propaganda) of states as the themes, designs, and even colors reveal information about nationalism, patriotism, and depictions of other countries. In short, stamps are being viewed in the same context as a state's official maps and web pages, all which are visible state information products.

Stamps convey topics about a state that it wishes to illustrate or display about its history, economy, culture, science, economic products or place in the world. Stamps may include distinctive events of history, such as a famous treaty or military battlefield site, or they may include famous political, military, literary, or scientific leaders. In essence, the state is "showing its place in the world" through the images and topics on its stamp issues. Some states choose to include maps on stamps, to show "where they are in the world," an important piece of diplomacy especially for new states on the world map. Some stamps show territorial possessions, contested borders, heritage discoveries and associations of specific cultures with specific places. Geographers and historians have been those who have looked at the stamp issues of states [19] [20] [26] [27] [28]. Some have looked at 
individual countries, including Argentina [29] [30], Ghana [31] [32], Mexico [33], Gabon [34], France [35] [36] [37] [38], Germany [39] [40] [41], New Zealand [42], New Zealand and Australia [38], Finland [43] [44] [45], Taiwan [46], Japan [47] [48] [49], Iraq [50], Iran [51], Belgium and Switzerland [52], Ireland and South Africa [53], China [54], the two Koreas [55], Sudan and Burkina Faso [56] [57], Russia/Soviet Union [58] [59] [60] [61] [62], Australia [63], Portugal [64], Burkina Faso [57], the United Kingdom [65] [66] and the United States [67]. Others have looked at regions, for example, East Asia [68], Europe [36], West Africa [69], the Arab World [70], Latin America [71] [72], New Central Asian and European States [73] and three Catholic European states [74].

Another topic studied about stamps relates to how they can be used to teach certain subjects. These include using stamps to teach biology [75], languages [76] [77] [78] [79] [80], Italian Culture [81], Hispanic culture [82], social studies [83] and Orientalism [84]. Other studies have looked at the language of stamps [85], tourism [86], disability [87], women and men [88] [89], medical history [90], emancipation [91], cultural exhibitions [35], propaganda [92] and maps as propaganda [93], history [94] and culture [95] [96] [97] [98]. A few studies have looked at how stamps actually have influenced public opinion and policy [99] [100]. These also include Cernada's [101] work on family and public health issues in Taiwan and Lefrere and Donic's [102] work on blood transfusions and disabilities [87].

There can be many different categories of stamp themes including indigenous cultures, nature (plants and animals), culture (music instruments, literary figures, religious heritage, architecture, national games, etc.), buildings (universities, parliaments, museums and religious structures), parks and recreation areas, sporting events and famous leaders in science [103], music [104], chemistry [105] [106], mathematics [107] [108], urology [109], mining [110], animal diversity [111], bees and bee hives [112] and blood donations [102]. Keep in mind that the major purposes of these and other stamps are to inform and educate the population and make viewers feel at home and identify with the specific subject matter in some way. In this context they form part of what some scholars consider "imagined communities" [113] [114] [115].

Among the many topics of stamps issued are those that relate to the environment. States can and do issue stamps for tourists (beaches, nature preserves, famous historical ruins and unique biological preserves) which relate to physical environmental bases [116]. But they also can be used to increase the awareness of problems facing a given country and also problems beyond its borders. For example, states could issue stamps about the shrinking of polar icecaps, threatened habitats of polar bears, about temperature increases that will bring about rising sea levels and disappearing coastlines, about massive deforestation which also increases surface temperatures and reduces biodiversity in tropical areas, or about the increased factory and auto emissions on urban quality of life.

What I am suggesting is that the "geopolitics of the visual" goes beyond a state's official web page or photographs about threatened and endangered bio- 
logical and human habitat zones. It can reach another level where the increased awareness is made apparent in postage stamp issues. That awareness can be and is seen in the number of environmental awareness stamps issued, but also the variety of themes depicted on those stamps. That awareness level may be evident on a much broader environmental space, such as a region or even worldwide. As scientists and concerned citizens acknowledge, most environmental problems are not restricted to a state's political borders, but extend well beyond to other countries and continents. What is noted below in the analysis is how some states have issued stamps with local themes whereas other countries have issued stamps with global themes. The case is made below that some states (and certainly not all) are issuing stamps with global warming and climate change themes that they hope will raise the environmental awareness of their citizens.

\section{The Database}

A question that surfaced early in this research was how to obtain or compile a complete list of stamps that depict global warming or climate change themes. For the philatelist the answer would be easy, that is, go through the six catalogues (9466 total pages) of the 2015 Scott's Standard Postage Stamp Catalogue [117]. These catalogues are issued annually and contain the numbers, description, colors, denominations and values (used and mint or unused) for every, or nearly every, stamp issuing country and territory. (Not all are official states as some are territories and dependencies of states, including Jersey and Guernsey islands, French Southern and Antarctic Territories, Tuvalu and Tristan da Cunha.) To search through all pages and look for specific issues about global warming and climate change would be a very daunting and time-consuming task. Any such effort would reveal that these categories comprise a very small percentage of the total stamps issued or total sets issued by any country. Another approach would be to access any list that others have compiled about these themes. I discovered two, which I am using in this research. One is a website by Mr. Panos Giannopoulos, a professional meteorologist and philatelist with the Greek National Meteorological Centre/Greek National Meteorological Service HNMS. His site was developed in 2008; it divides materials about global warming and climate change into five major categories: general, causes and effects, international cooperation and protect the Polar Regions [118]. These attractive colorful webpages clearly illustrate the topics, designs and colors of 168 stamps from 49 different countries plus the United Nations. The second source I used was developed by two professional meteorologists, Dr. Garry Toth, retired from the Meteorological Service of Canada and Dr. Hillger, research meteorologist for NOAA and also Colorado State University. Hillger developed a website [119] that lists 347 items related to global warming and climate change; it includes postage stamp issues, cachets (illustrative designs on envelopes) and postal mark cancellations from 65 countries plus the United Nations offices in New York, Geneva and Vienna. Their website contains no illustrated materials, but is especially useful for those interested in using stamps in research projects. Supple- 
menting the website is a 2013 article Toth and Hillinger published in Weatherwise on "A Philatelic History of Climate Change" [120].

I used both databases, plus other stamps I discovered going through the stamp issues for a number of countries. I compiled a list of stamps that related to global warming and climate change. That database included stamps issued by 89 different countries and territories and the three United Nations offices (New York, Geneva and Vienna), each which issues its own stamps on the same theme). It is important to mention here that I believe there are likely many more stamps on these topics than I am using. One could easily imagine including stamps issued about energy conservation, sustainability, wildlife and plant conservation and green "ethics" that are related to the overall themes of this paper. Be that as it may, I believe the current database I prepared, based on Toth and Hillinger [120] and Giannopoulos [118], is a fair representation of stamp issues related to global warming and climate change. Figure 2 shows the countries that have issued one or more stamp with an environmental theme. Not surprisingly, most are in the Global North, especially Europe, but also there are examples from all continents. (I am not considering cachets and postal cancellations that related to the two main subjects of this paper).

\section{Results}

First I address some general comments about the findings and stamp issues; then I will focus on specific findings. The 89 postal issuing units, plus the three United Nations offices (New York, Geneva and Vienna) varied significantly in the number and variety of stamps related to global warming and climate change. I counted about 125 different sets of stamps (a set may include one, two or a half dozen stamps) and over 280 different stamp issues. Almost three-quarters of the stamps have been issued since 2000 and almost one-third since 2010, which suggests the topic remains an important subject for countries. Very few stamps (less than a handful) about these climate conditions were issued before 1980.

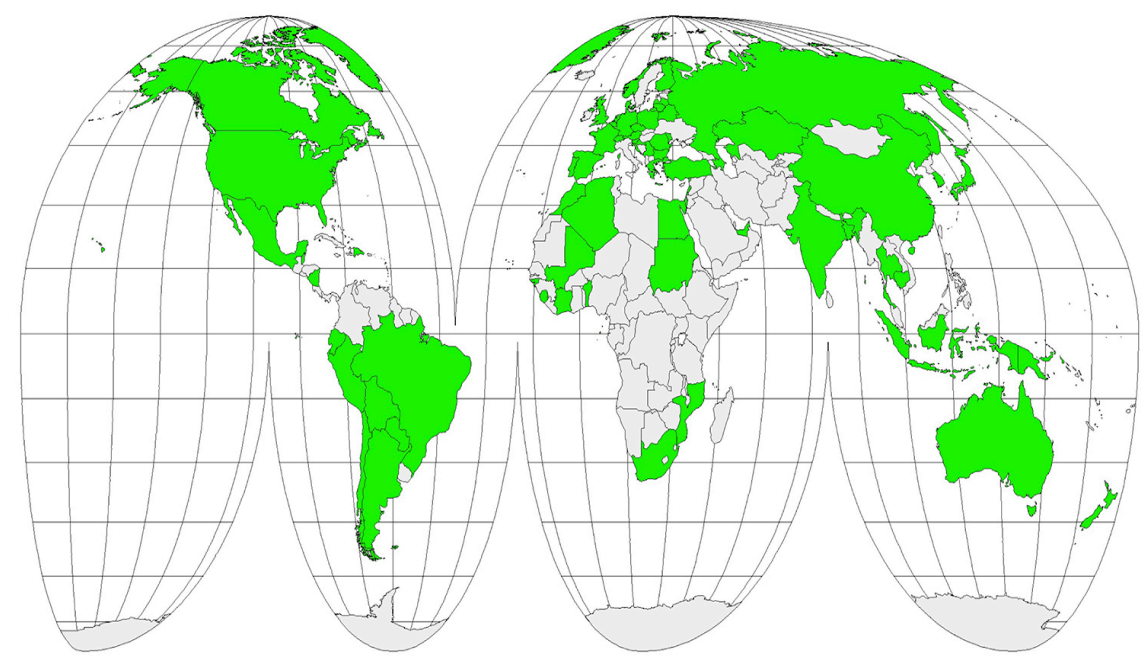

Figure 2. Countries issuing stamps about global warming themes. 
The range of topics depicted on stamps covered the waterfront of themes related to these themes (Table 1). They include generic topics such as sustainability, environmental quality, destructive features such as the greenhouse effect, fossil fuel emissions, increased $\mathrm{CO}_{2}$ emissions, acid rain, dependency on automobiles, shrinking glaciers and ice caps, the destruction of polar bear habitats, deforestation, desertification, coral reef destruction as well as some positive developments such as planting trees, sustainability initiatives, environmental protection programs, commemorative years and days such as the International Polar Year, World Environment Day and International Climate Change conferences.

Table 1. Examples of major themes of stamps about global warming and climate change.

\begin{tabular}{|c|c|}
\hline Theme & Country \\
\hline Acid Rain & France, Micronesia \\
\hline Civic Virtues & Spain \\
\hline Climate Change & Belgium, Bolivia, Aruba, Faroe Is., Paraguay \\
\hline $\mathrm{CO}_{2}$ Research & Austria, French Southern and Antarctic Territories \\
\hline Conferences & $\begin{array}{l}\text { Belarus, Brazil, Poland, Germany, Japan, Sudan, } \\
\text { South Africa, Morocco, Maldives }\end{array}$ \\
\hline Cooperation on Antarctic Research & Russia and Australia \\
\hline Desertification & Bolivia, Brazil, Sudan, United Arab Emirates \\
\hline Energy Conservation & China \\
\hline Environmental Care/Protection & Cambodia, China, Indonesia, Lebanon, Tonga \\
\hline $\begin{array}{l}\text { Forest Conservation and Tree } \\
\text { Planting }\end{array}$ & Argentina, Japan, Mexico, Micronesia \\
\hline Glacier Retreat and Melting & South Georgia, Switzerland \\
\hline Global Warming & $\begin{array}{c}\text { Aruba, Bolivia, China, Faroes, Israel, Maldives, } \\
\text { Norway, Tuvalu, U.S. }\end{array}$ \\
\hline Greenhouse Effect & Kiribati, Tuvalu, Micronesia \\
\hline Ozone Layer & $\begin{array}{c}\text { Brazil, Burundi, French Southern and Antarctic } \\
\text { Territories, Germany }\end{array}$ \\
\hline $\begin{array}{l}\text { Preserve Polar Regions, Including } \\
\text { International Polar Year }\end{array}$ & $\begin{array}{c}30 \text { countries, including Argentina, Belarus, Brazil, } \\
\text { Canada, Chile, China, Comoros Is., Dominican Republic, } \\
\text { Finland, Greece, Iceland, India, Mali, Maldives, } \\
\text { Mozambique, Nicaragua, Romania, Russia, Slovenia, } \\
\text { South Korea, U.S. }\end{array}$ \\
\hline Projection of El Niño & Peru \\
\hline Sea Level Rise & Kiribati \\
\hline Sustainability & Brazil, South Africa \\
\hline Water Protection Issues & Bangladesh, France, Portugal \\
\hline Weather Extremes & Belize, New Zealand, Peru \\
\hline World Environment Day & $\begin{array}{c}\text { China, Egypt, Indonesia, Mexico, Sierra Leone, } \\
\text { Thailand, Turkey }\end{array}$ \\
\hline
\end{tabular}




\subsection{Categories of Topics on Global Warming and Climate Change}

I classified the stamps into seven major categories, each which defines a specific topic related to global warming and climate change. I illustrate examples of stamps in each of these categories as well. One notes easily that these are very colorful and attractive stamps with information presented in the words of images.

The first category identifies international or global conferences, that is, meetings of regional or international bodies that address one or more topics related to global warming and climate change. Countries that have issued stamps with this theme include Brazil and South Africa (sustainability), climate change (Denmark, Germany, Japan and Poland), desertification (United Arab Emirates, Bolivia and Sudan) and Brazil (Figure 3).

Second are those that have issued a stamp or souvenir sheet or set of stamps related to Polar Regions. Celebrating the International Polar Year in 2009 was the focus of most stamps in this category. Nearly thirty countries issued stamps for this Year, including many tropical and subtropical countries where there are no glaciers, no polar bears, no penguins and no ice. Examples of countries that have issued these stamps include China, Mali, Denmark, Comoros Islands, Romania, Belarus, Greece, Bulgaria, Finland, Switzerland, Dominican Republic, Ecuador and Kazakhstan (Figure 4).

Third are stamps with specific global warming and climate change themes. Nearly a dozen places have issued these stamps; they include countries in the low and high latitudes, including the Maldives, Norway, Bolivia, China, Aruba, Belgium, Belarus, Kiribati, Tuvalu and the Faroe islands. Some of the tropical islands will be affected by rising sea levels. An enlarged ozone layer and increased levels of $\mathrm{CO}_{2}$ were themes on stamps of Austria, Burundi and Ecuador (Figure 5 and Figure 6).

Fourth are stamps issued about international environmental years and days.
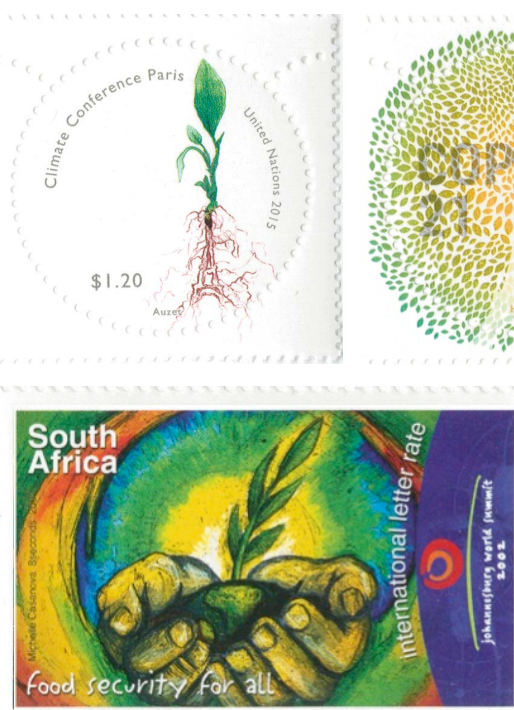
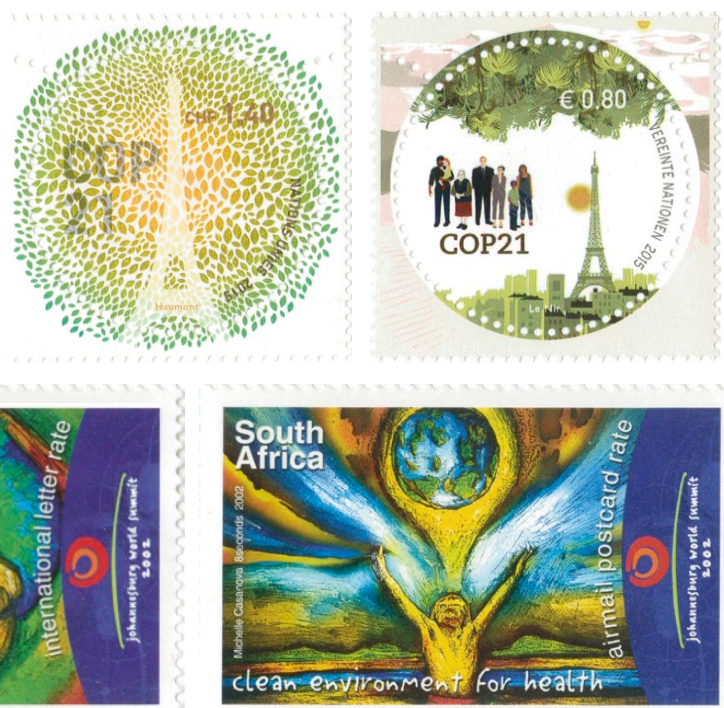
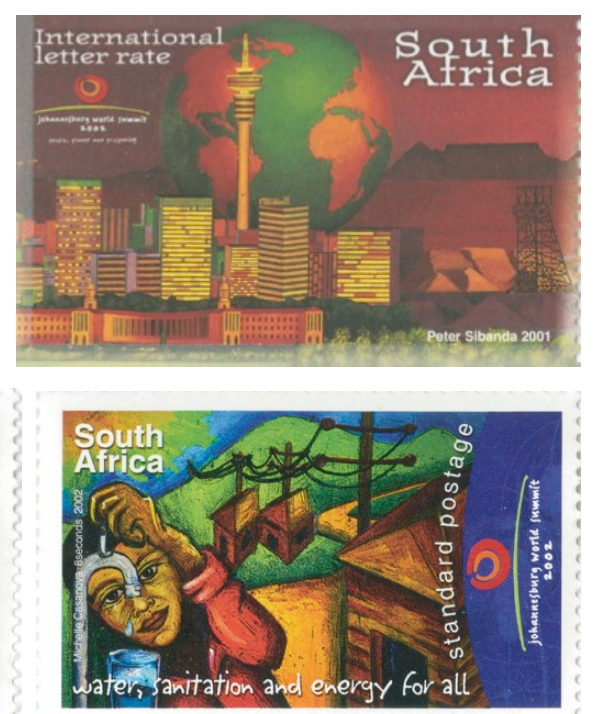

Figure 3. Stamps issued about international conferences on climate change. 

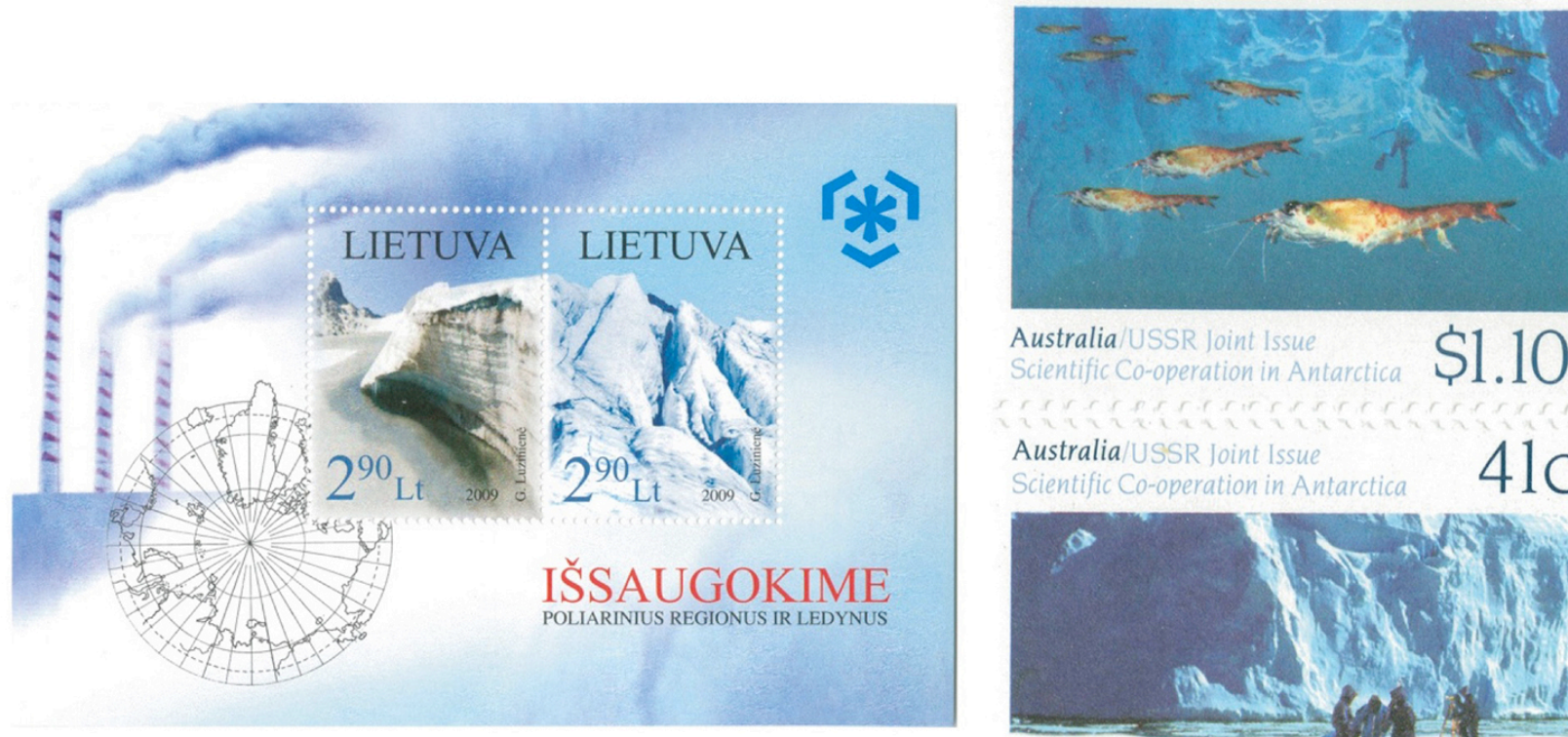

Australia/USSR Joint Issue
Scientific Co-operation in Antarctica $\quad \$ 1.10$
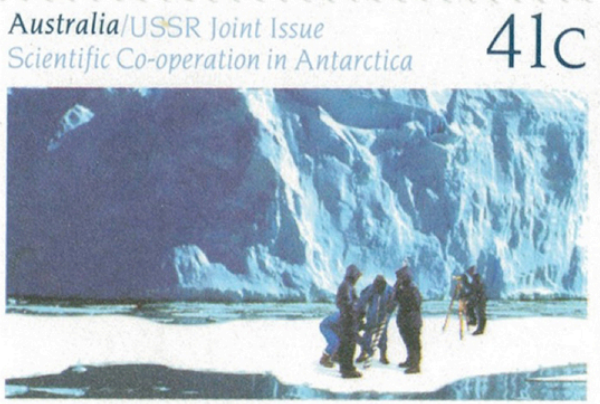

Figure 4. Stamps issued about how global warming affects Polar Regions.
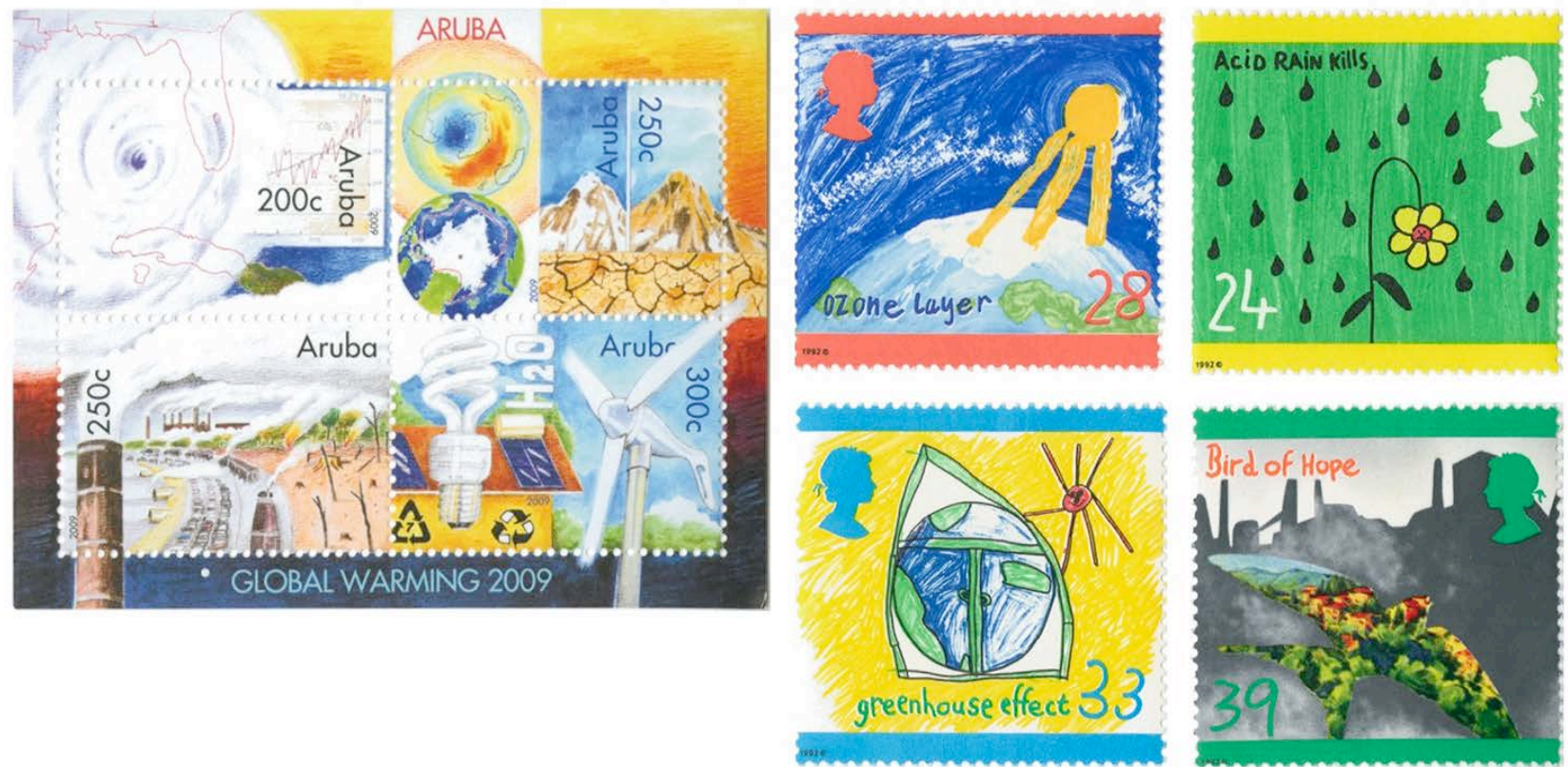

Figure 5. Stamps issued about global warming and climate change.

These include World Environment Day, Environment Quality, and Environmental Protection. More than ten countries have issued these stamps, including China, Turkey, Israel, Indonesia, Lebanon, Paraguay, Mexico, Thailand and Egypt (Figure 7). Turkey has annually issued very colorful stamps for World Environment Day since 1992.

Fifth are places that have included maps as a theme of their stamp issues. 

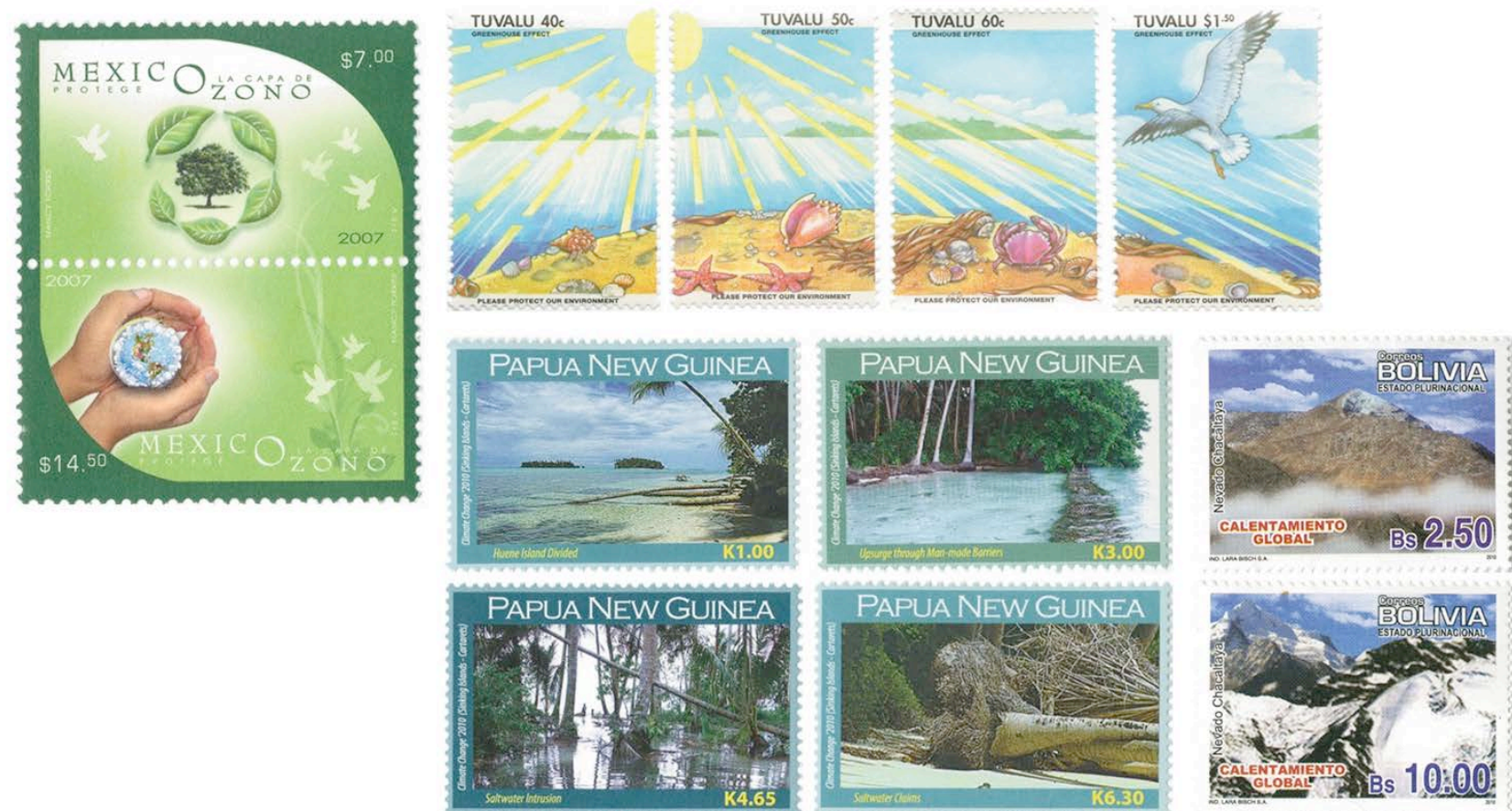

Figure 6. Stamps issued about global warming and climate change.
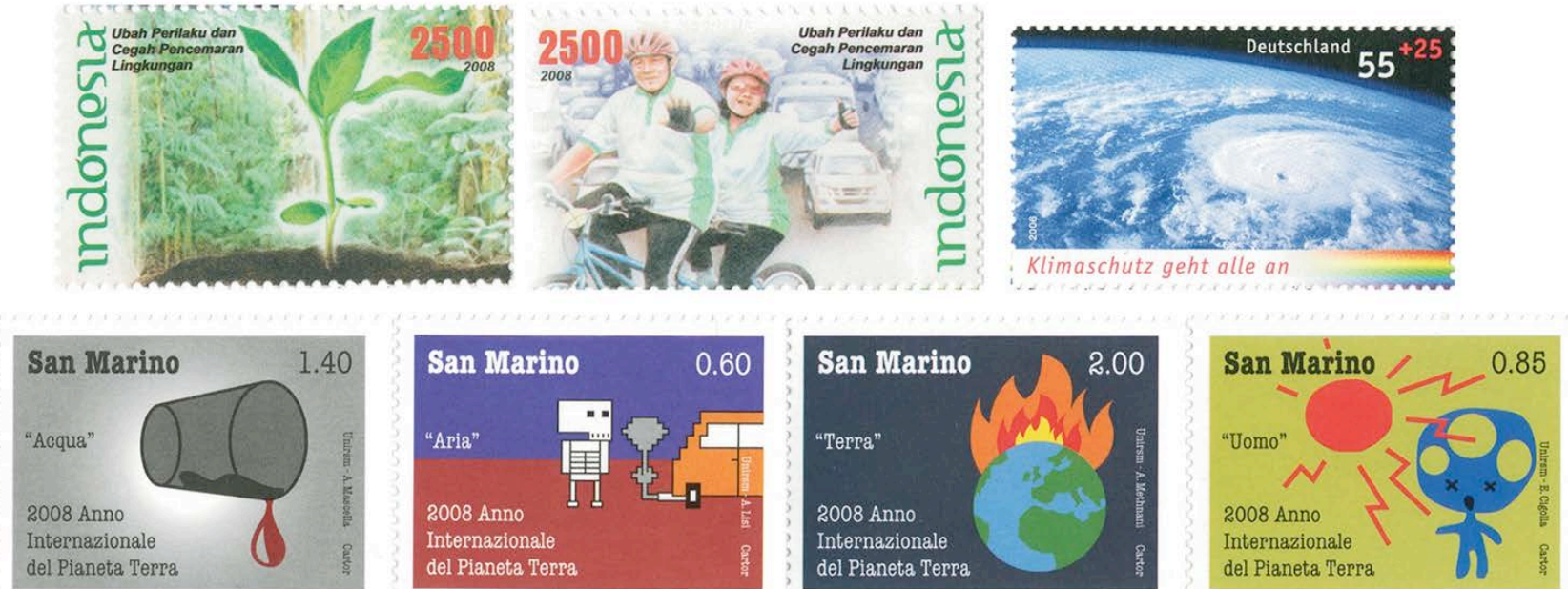

Figure 7. Stamps issued about international environmental years or days.

More than two-dozen countries issued stamps with maps. They were also an important part of many visual messages. They can be grouped into three categories: global, regional and state or national (Figure 8). Global maps usually depicted a hemisphere, and usually showed Europe, Africa and the Americas. Thailand, Belgium, Cambodia, Poland and Aruba issued stamps with world maps. Aruba's stamp about the greenhouse effect included one of hurricanes in the Caribbean and another on Polar Regions. The preservation of Polar Regions was shown on stamps for more than thirty countries including the Dominican Republic, Finland, Mozambique, Romania, Kazakhstan and the British Antarctic Territory. 


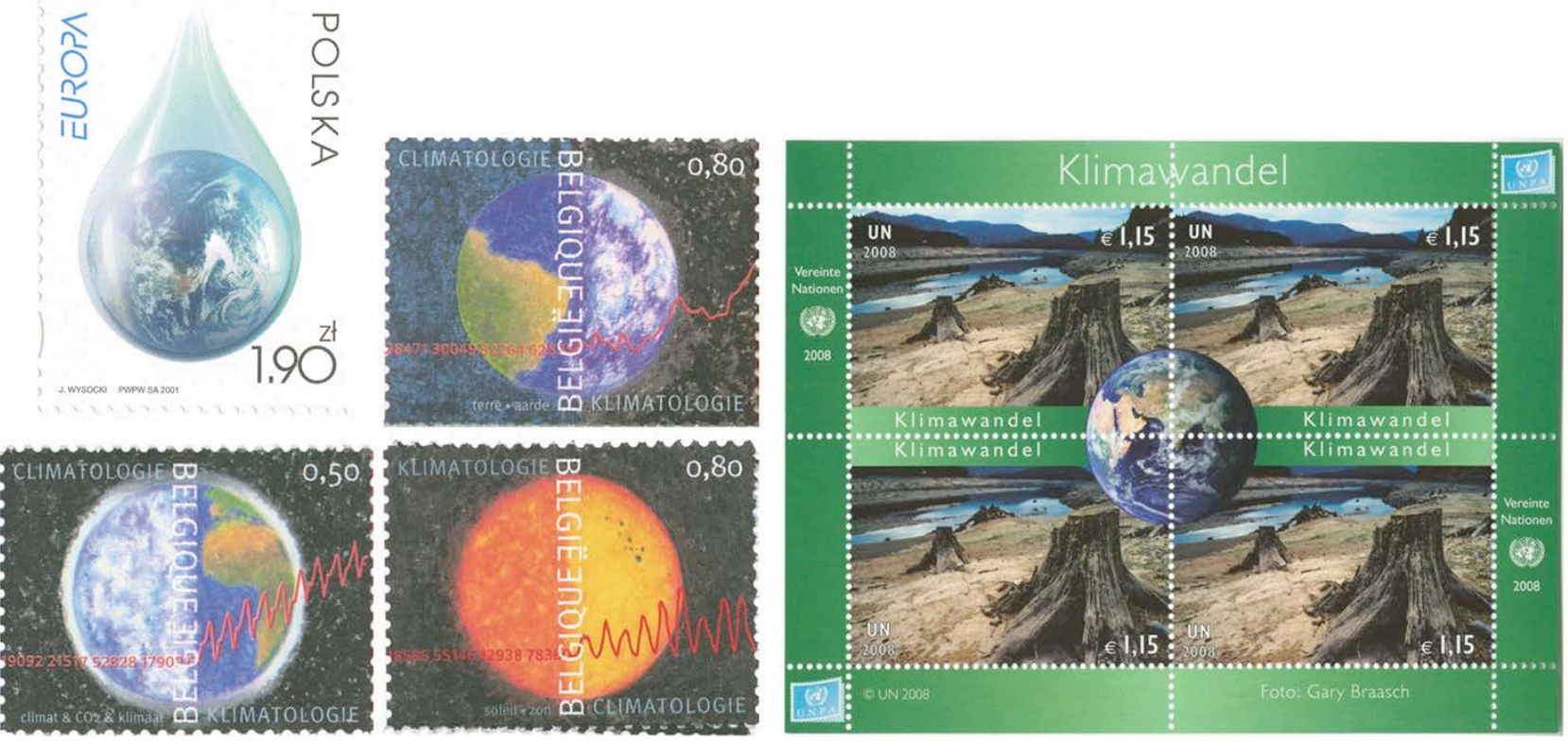

Figure 8. Stamps issued about climate change that contain maps.

Polar bears often appeared with maps of Antarctica. Regional maps were mostly about the circumpolar regions, especially Antarctica and surrounding seas and territories; a regional map of the Caribbean and Central American appeared on a stamp of Belize. Only a few stamps showed specific countries; examples were of Brazil, Mexico, New Zealand and Argentina. Belgium called attention to global warming and $\mathrm{CO}_{2}$ levels, Thailand, Mexico, Turkey and Morocco called attention to World Environment Day, Iceland and Greenland to a shrinking ice sheet, Argentina and Chile to retreating ice sheets, and Kiribati to the impact of a rising sea level to these Pacific islands. New Zealand issued a colorful set of six stamps for extreme weather.

Sixth are animals and landscapes that are frequently associated with global warming and climate change. A common feature on many stamps about polar environments was a polar bear; more than a dozen countries included them in designs along with an ice surface; penguins were also common, less common where seals and whales. Sea turtles were associated with Greenpeace, an international organization concerned with alerting humankind to the harmful effects of climate change and the killing of threatened species. This organization was depicted on four stamps issued by São Tome and Principe in 1996 to celebrate the organization's 25th anniversary.

Seventh, I identify miscellaneous themes. These include cartoon characters (Greenland, which showed ice caps and a polar bear), children's drawings about global warming themes (Great Britain in 1992), severe weather conditions (Belize, Peru and New Zealand), deforestation (Argentina and Japan), sea level rise (Kiribati), general ecology themes (Australia and Netherlands), water protection (France), preparation for El Niño (Peru), energy conservation (China) and civic values (Spain) (Figure 9). 

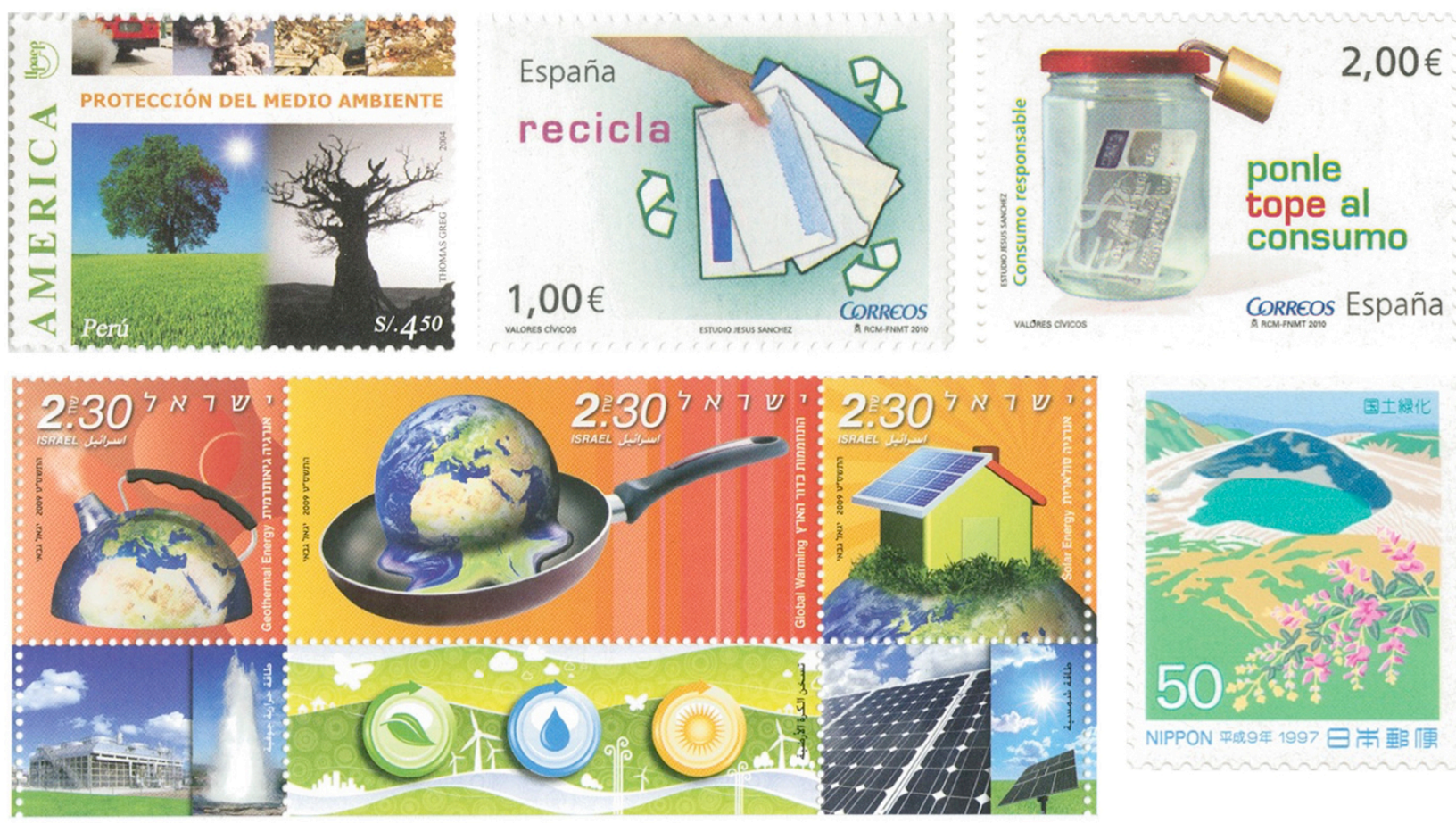

Figure 9. Miscellaneous topics about climate change and global warming.

\subsection{Colors}

There are two additional topics that are important in analyzing the content of these environmental stamps: colors and phrases. Even a casual observer examining the stamps issued about global warming and climate change would likely be struck by the bright colors used. Color is an important element in looking at visual materials as these are likely to arouse emotions about the topic or the theme being illustrated. In a political context, the color may also convey some meanings about the culture itself. Most of the environmental stamps are multi-colored and use what might be termed "soft" colors, that is, those that are eye-pleasing and likely to be appealing to the viewer. Several examples illustrate this point. Stamps about polar and circumpolar regions and topics are predominantly light blue or blue and white mixes. These are a "soft blue", the color associated with blue skies and seas, lakes and oceans. White is used for ice surfaces, glaciers and, of course, polar bears. Blacks and whites are used for penguins; the skies are often different shades of blue. Yellows and yellow-greens are used to depict increased earth temperatures, desertification and aridity conditions. Greens, soft and deep, are used to depict deforestation, tree planning, grasslands and even colorful plants. Green is associated with environmental protection and management. Dark browns are associated with polluted conditions, specifically industrial pollution and automobile usage. Colors are not to be ignored when looking at the images, whether photographs or artistic renderings that states use to illustrate causes of global warming or remedies for a more livable environment. Multiple dark colors are used also to depict scenic landscapes and biodiversity as well as violent weather conditions, such as storms, lightening, high 
winds and pending disasters, and, of course, polluted air. The United Nations issued some of the most colorful environmental stamps that conveyed multiple themes related to climate change and global warming.

\subsection{Words and Phrases}

Most of the stamps had only images of landscapes and environments as part of the image, however, a number also included some wording alongside the colorful images. This wording was considered important to these countries as it called attention to not only the visual images depicted, but also to some specific issue that might affect that country or its environment. The purpose of the phrase was to raise awareness of global warming and climate change. A few examples illustrate this point. Indonesian stamps (2007) inserted the words "Kick the Habit". Maldives stamps (1991) used the phrase "Melting Ice Could Cause Sea Level Rise", a phrase that certainly applies to this Indian Ocean state. This country was one of the first to call attention to sea level rise and is one that is likely to be severely impacted by global warming. The Netherlands Antilles issued a series (2008) that used these words: "Causes, Victims and Hope". South Africa issued a 2002 set that had "People, Planet and Prospects" on three stamps issued for the Johannesburg international conference on sustainability. Belarus issued a stamp with the letters "SOS" to call attention to global environmental crises. Latvia in 2009 had a stamp that included the phrase "Preserve the Polar Regions and Glaciers". Tuvalu, a South Pacific Island mini-state, issued 15 colorful stamps in 2007, each with a word about some feature related to global warming; examples of words were $\mathrm{CO}_{2}$ emissions, Melting Ice Caps, Deforestation, Traffic, Erratic Weather Types, Habitat Destruction, Coral Reefs and Industrialization. Bangladesh issued a stamp in 2008 for World Health Day with the phrase "Protecting Health from Climate Change". The United Nations issued a number of stamps about climate change and global warming in 1993, 2001 and 2008. Many of these colorful sets conveyed multiple themes.

\section{Analysis}

I identify six major features from the above stamp issues. First, the topics of global warming and climate change are recognized as being of international importance. The stamp-issuing countries are not only the Global North countries of Europe and North America, but include those in the Caribbean, South Pacific and also Sub Saharan Africa, South Asia, Southeast Asia and the Middle East and North Africa. The eighty-plus countries include a global mix. These findings suggest that it is not only the Rich World that has this environmental interest at heart, but those in the Global South countries and regions as well.

Second, and related to the point just made, there are both very large and very small countries that have issued stamps about one or more global warming and climate change theme. India, Australia, Canada, Germany, the United Kingdom, Brazil, China, Mexico, Russia and the United States are in this mix as well as a number of mini-states, including some whose futures are likely to be negatively 
impacted by continued temperature and sea level increases. African countries and also the Maldives, Kiribati, Micronesia and Aruba fall into this category.

Third, the stamps issued by the United Nations merit special attention as this international organization is a "sounding board" for issues that affect all humankind and all environments. The UN stamps issued by the New York, Geneva and Vienna offices are usually not single issues, but "strips" of three or four very colorful stamps that profusely illustrate a wide variety of themes. Examples include 1993 stamps issued by the New York office for the theme "Environment and Climate". These include a chameleon, palm trees, the top and bottom of a tornado funnel cloud and a bird of paradise. "Climate Change" was a subject in 2001 of stamps for all three cities. New York's issues depicted a Canadian goose, greenhouse gases, butterflies, icebergs, penguins, solar collector and hand planted gingko trees. The Geneva stamps showed a lizard, flora, shoreline, windmills, non-polluting industry, a solar oven and city skyline. The Vienna stamps showed solar panels, autos, bikes, balloons, sailboats, lighthouse, train, and traffic signals. The 2008 Climate Change stamps for the Geneva UN office showed a polar bear, ship and sea ice and the Vienna office showed smokestacks, cut trees and similar themes as the Geneva office.

Fourth, the stamps issued to promote increased awareness of environmental issues covered a wide range of topics that governments and the general public consider important. These include not only general topics such as global warming and climate change, but more specific ones such as tropical forest deforestation, coral reef destruction, acid rain, desertification, energy conservation, civic virtues and shrinking glaciers. A large majority of the stamps portray physical landscapes under threat from global warming, sea level rise, loss of biodiversity, etc. Only a few show cities and of those that do, industrial pollution and cars are the major themes illustrated. Also most stamps do not show people. Conservation and preservation themes, including sustainability and green energy projects, are illustrated on some, not a majority of the stamps. As noted above, it is the United Nation stamps that seem to depict the widest variety of topics related to environmental issues. Since the UN is the major global forum for discussing such topics, it is not surprising that this organization would take a lead in issuing sets of stamps with comprehensive environmental messages.

Fifth, while the themes of stamps discussed above and illustrated in this manuscript cover a vast array of topics, issues and problems related to the natural environment and to human-nature intersections, there are a number of topics that are not on stamps or are on very few. For natural and social scientists interested in environmental conditions and policies and for governments interested in the same, there are very few stamps on water conservation, recycling, green energy engineering projects, sustainable architecture and environmental education initiatives. I identified no stamps that illustrated the hazards associated with nuclear energy use or halting the testing of military weapons or addressing contaminated drinking water due to outdated water delivery systems or the overuse of chemical fertilizers in soils or the hazardous work and living spaces of work- 
ers or consumer safety labeling on foods, toys and a wide variety of household consumer products including cars, iPhones, computers and other technology innovations.

Sixth, and finally, I am surprised by the number of countries that still, at least from my reading of the stamp issues, have not issued stamps about one or more environmental themes. Over 80 nations have issued them, but that means more than 100 states and territories have not. This includes most countries in Latin America, Sub Saharan Africa and the Greater Middle East (from Morocco to Kazakhstan). African countries have issued the fewest stamps. A good number of stamps have been issued by South, Southeast and East Asian countries. What is noteworthy about this point is that although environmental issues are paramount on a global scale, as evidenced by those signing environmental-related treaties such as climate change and biodiversity, many have not issued stamps about the topics discussed above. Some of these, and this is a topic for separate discussion, have issued stamps about Hollywood stars, famous sports figures, Renaissance art and cartoons, all which generate income and portray little or nothing about the country's history and culture, let alone its environmental concerns.

\section{Summary and Future Directions}

This is a first effort to look at global environmental themes and how they are portrayed on stamps of states. I have focused specifically on the "visual geopolitics" associated with global warming and climate change as environmental themes, that is, the role of states and governments in informing and alerting their citizens about global topic, but also ways they seek to resolve related problems either individually or as partners in regional and global treaties and agreements. As I look at these related issues, there are clearly other environmental topics that could also be examined and which also appear on stamps. Let me suggest four topics that will expand our knowledge of the geopolitics/visualization thinking.

The first would examine stamp issues about additional international conferences on environmental topics including desertification, deforestation, declining biodiversity, water, green energy and sustainable development. Related to these would be stamps that have consumer protection, disease prevention, conservation, preservation and generic quality of life issues of children, mothers, the elderly and rural communities. Many countries have issued stamps on these topics. A second topic is a careful and detailed examination of the official web pages of states and what information (text, maps, photos and graphs) is provided about environmental topics. One might compare states in different groups, for example, the web pages of those affected most by sea level rise (South Pacific and Indian Ocean islands), deforestation (Southeast Asian, Central Africa, Central and South American countries) and those most impacted by high levels of $\mathrm{CO}_{2}$ in the atmosphere (East and South Asia and some countries in eastern Europe 
with heavy mining and industrial heritages). A third topic would examine those who designed the stamps and produced the web pages. Are the designs that are selected the efforts of residents of the stamp-issuing country or are they the product of someone from another country? I suspect a close inspection of many topics and designs would reveal the artists and photographs came from beyond the country's borders. This finding especially seems to fit the many stamps with polar and circumpolar topics, especially in tropical areas. And one might also suspect that many photographs on a country's webpage about various environmental issues came from someone or environmental group living outside the country. A fourth and final topic would be to examine the use of maps and photographs more specifically, especially as they are used as ways to influence and inform citizens and children of all ages in the Global North and South about the regional and global nature of pressing environmental problems. Also it would be worthy knowing how effective maps, and what maps, are being used to promote greater regional and international agreements and treaties. Global maps, it might be argued, are probably effective ways to inform and educate the increasing visual oriented public about global topics, including those associated with global warming and climate change, but also improve the overall human condition.

What is certain is there remains much additional research that needs to be done not only on identifying specific environmental problems and taking or making steps to understand and resolve them. But there is a need for effective communication strategies to increase the awareness of the youth, the adults and the senior citizens as well as political and environmental oriented groups in all countries. The "visual" world is much with us and the producers of visual information include not just those that are environmentally related but those that produce films, advertisements, cartoons, photographs and stamps. All are increasingly important in "delivering the messages". The "geopolitics of the visual" will become a more important ingredient in state news production in the future, whether in increasing environmental awareness to the general public or reporting on national and regional disasters or strengthening the school curricula from elementary grades through postgraduate degree training or citizen awareness programs. Increasing that awareness can be accomplished by environmental stamps being issued on a regular basis, not only once every five or ten years. Greater awareness will become evident if children are asked to come up with designs for stamp issues, museums develop displays about past and present environmental conditions that are accompanied by maps and photographs, countries promote actively National Green Days for planting trees, preserving endangered plant and animal habitats and awards being given to schools, companies and organizations that made sustained contributions to increasing environmental awareness at local and national scales. The opportunities for ongoing interdisciplinary, transdisciplinary and international collaborative research on global warming and environmental change, and other areas, will be among the most effective ways to provide for a more environmentally aware, just, and peaceful world for all the planet's citizens [121] [122] [123]. 


\section{Acknowledgements}

The author thanks Donna Gilbreath for assistance in preparing this manuscript.

\section{References}

[1] Castells, M. (1996) The Information Age: The Rise of the Network Society. Blackwell, Oxford.

[2] Brunn, S.D. (2015) Language, Identity and Boundary Disputes in the Emerging Virtual State: Challenges from the Internet, Google and Social Media Worlds. European Journal of Geopolitics, 2, 24-43

[3] Brunn, S.D. and Cottle, C.D. (1997) Small States and Cyberboosterism. Geographical Review, 87, 240-258. https://doi.org/10.2307/216007

[4] Campbell, D. and Power, M. (2010) The Scopic Regime of Africa. In: MacDonald, F., Hughes, R. and Dodds, K.J., Eds., Observant States. Geopolitics and Visual Culture, I. B. Tauris, London and New York, 167-198.

[5] Der Derien, J. (2010) Imaging Terror: Logos, Pathos and Ethos. In: MacDonald, F., Hughes, R. and Dodds, K.J., Eds., Observant States. Geopolitics and Visual Culture, I. B. Tauris, London and New York, 23-40.

[6] Jackson, M.J. and Purcell, D. (1997) Politics and Media Richness in the World Wide Web: Representations in the Former Yugoslavia. Geographical Review, 87, 219-239. https://doi.org/10.2307/216006

[7] Rosenau, J.N. (2002) Information and the Skills, Networks and Structures that Sustain World Affairs. In: Rosenau, J.N. and Singh, J.P., Eds., Information Technologies and Global Politics. The Changing Scope of Governance, State University of New York Press, Albany, NY, 275-288.

[8] Singh, J.P. (2002) Introduction: Technologies and the Changing Scope of Global Power and Governance. In: Rosenau, J.N. and Singh, J.P., Eds., Information Technologies and Global Politics. The Changing Scope of Power and Governance, State University of New York Press, Albany, 1-38. https://doi.org/10.1201/9781420038507.ch0

[9] Steinberg, P.E. and McDowell, S.D. (2003) Mutiny on the Bandwidth: The Semiotics of Statehood in the Internet Domain Name Registries of Pitcairn Island and Niue. New Media \& Society, 5, 47-67. https://doi.org/10.1177/1461444803005001907

[10] Wilson, M.I. (2001) Location, Location and Location: The Geography of the Dot Com Problem. Environment and Planning B, 28, 59-72. https://doi.org/10.1068/b2692t

[11] Zook, M.A. (2000) The Web of Production: The Economic Geography of Commercial Internet Content Production in the United States. Environment and Planning $A, 32,411-426$. https://doi.org/10.1068/a32124

[12] Brunn, S.D. (2015) Geopolitics in a Topsy-Turvy World: Ten Futuristic Perspectives. European Journal of Geopolitics, 3, 21-49.

[13] Mirzoeff, N. (1998) What Is Visual Culture? In: Mirozeff, N., Ed., The Visual Cultural Reader, Routledge, London, 3-13.

[14] Panofsky, N. (1982) Meaning in the Visual Arts. University of Chicago Press, Chicago.

[15] Peirce, C.S. (1902) Logic as Semiotics: The Theory of Signs. Dover, Mineola, NY.

[16] Rose, G. (2007) Visual Methodologies: An Introduction to the Interpretation of Visual Materials. Sage, London. 
[17] Altman, D. (1991) Paper Ambassadors: The Politics of Stamps. Angus and Robertson, North Ryde, Australia.

[18] Child, J. (2005) The Politics and Semiotics of the Smallest Icons of Popular Culture. Latin American Research Review, 40, 108-137. https://doi.org/10.1353/lar.2005.0003

[19] Scott, D. (1995) European Stamp Design: Semiotic Approach to Designing Messages. Academy Editions, London.

[20] Scott, D. (2002) The Semiotics of the Lieu de Mémoire: The Postage Stamp as a Site of Cultural Memory. Semiotica, 2002, 107-124. https://doi.org/10.1515/semi.2002.069

[21] Boulding, K. (1959) National Images and International Systems. Journal of Conflict Resolution, 3, 120-131. https://doi.org/10.1177/002200275900300204

[22] Gottman, J. (1952) The Political Partitioning of our World: An Attempt at Analysis. World Politics, 4, 512-519. https://doi.org/10.2307/2008963

[23] Pike, A. (2009) Geography of Brands and Branding. Progress in Human Geography, 33, 619-645. https://doi.org/10.1177/0309132508101601

[24] Pike, A. (2011) Brands and Branding Geographies. Edward Elgar, Cheltenham. https://doi.org/10.4337/9780857930842

[25] Pike, A. (2015) Origination: The Geography of Brands and Branding. WileyBlackwell, New York and London.

[26] Reid, D.M. (1984) The Symbols of a Postage Stamps: A Source for the Historian. Journal of Contemporary History, 19, 223-249. https://doi.org/10.1177/002200948401900204

[27] Stamp, L.D. (1966) Philatelic Cartography: A Critical Study of Maps on Stamps with Special Reference to the Commonwealth. Geography, 51, 179-197.

[28] Wellsted, W.R., Rossiter, J. and Flower, S. (1986) The Stamp Atlas. MacDonald, London.

[29] Bushnell, D. (1982) Postal Images of Argentine Proceres: A Look at Selective Myth-Making. Studies in Latin American Popular Culture, 1, 91-105.

[30] Child, J. (2004) The Politics and Semiotics of Argentina Postage Stamps. MACLAS Middle Atlantic Council of Latin American Studies, 18, 55-85.

[31] Adedze, A. (2009) Ghana at Fifty: A Review of Ghana's Official History through Postage Stamps. CODESRIA, 12th General Assembly, Yaoundé, Cameroon, 11-12 July 2009.

[32] Odotei, I.K. and Awedoba, K.K. (2016) Chieftaincy in Ghana Culture, Governance and Development. Sub-Saharan Publisher and Trader, Accra, Ghana.

[33] Hoya, H. (2002) Fresh Views on the Old Past. The Postage Stamp of the Mexican Bicentennial. Studies in Ethnicity and Nationalism, 12, 19-44. https://doi.org/10.1111/j.1754-9469.2012.01158.x

[34] Levin, J. (2004) Sculpted Poets: Architectural Decorations on Gabonese Stamps. African Arts, 37, 62-96. https://doi.org/10.1162/afar.2004.37.2.62

[35] Adedze, A. (2004) Re-Presenting Africa: Commemorative Postage Stamps of the Colonial Exhibition of Paris (1931). African Arts, 37, 58-95. https://doi.org/10.1162/afar.2004.37.2.58

[36] Davies, N. (2011) Vanished Kingdoms. The History of Half-forgotten Europe. Penguin, London.

[37] Hoisington, W.A. (1972) Politics and Postage Stamps: The Postal Issues of the French State and Empire, 1840-1944. French Historical Studies, 7, 349-367. https://doi.org/10.2307/286219 
[38] Marshall, B. (2000) The First Map Stamps of Australia and New Zealand. The Globe, 50, 19-26.

[39] Di Napoli, T. (1980) Postage Stamps and the Teaching of GDR culture of Civilization. Die Unterrichtspraxis/ Teaching German, 13, 193-205. https://doi.org/10.2307/3530665

[40] Jung, U.O. (1981) Germany through Stamps. Die Unterrichtspraxis/ Teaching German, 14, 246-259. https://doi.org/10.2307/3530563

[41] Lauritzen, F. (1988) Propaganda Art in the Postage Stamps of the Third Reich. The Journal of Decorative and Propaganda Arts, 10, 62-79. https://doi.org/10.2307/1504019

[42] Collins, R.J.G., Fathers, T.M. and Nash, D.E.G. (1938) The Postage Stamp of New Zealand. Philatelic Society of New Zealand, Wellington.

[43] Raento, P. (2006) Communicating Geopolitics through Postage Stamps: The Case of Finland. Geopolitics, 11, 601-629. https://doi.org/10.1080/14650040600890750

[44] Raento, P. and Brunn, S.D. (2005) Visualizing Finland: Postage Stamps as Political Messengers. Geografiska Annaler. Series B, Human Geography, 87, 145-164. https://doi.org/10.1111/j.0435-3684.2005.00188.x

[45] Raento, P. and Brunn, S.D. (2008) Picturing a Nation: Finland and Postage Stamps, 1917-2008. National Identities, 10, 49-75. https://doi.org/10.1080/14608940701819777

[46] Deans, P. (2005) Isolation, Identity and Taiwanese Stamps as Vehicles for Regional Legitimation. East Asia, 22, 8-30. https://doi.org/10.1007/s12140-005-0007-5

[47] Dobson, P. (2002) Japanese Postage Stamps: Propaganda and Decision Making. Japan Forum, 14, 21-39. https://doi.org/10.1080/09555800120109014

[48] Dobson, P. (2005) The Stamp of Approval: Decision-Making Processes and Politics in Japan and the UK. East Asia, 22, 56-76.

https://doi.org/10.1007/s12140-005-0009-3

[49] Frewer, D. (2002) Japanese Postage Stamps as Social Agents: Some Anthropological Perspectives. Japan Forum, 14, 1-19. https://doi.org/10.1080/09555800120109005

[50] Reid, D.M. (1993) The Postage Stamp: A Window on Saddam Hussein's Iraq. Middle East Journal, 47, 77-89.

[51] Oliasy, R., Agha-Aligol, D., Shokouhi, F. and Lamehi-Rachti, M. (2009) Analysis of Iranian Postage Stamps Belonging to the Qajai Dynasty (18th-20th Centuries) by Micro-PIXE. X-Ray Spectrometry, 38, 479-486. https://doi.org/10.1002/xrs.1202

[52] Schwarzenbach, A. (1999) Portraits of a Nation: Stamps, Coins, Banknotes in Belgium and Switzerland, 1880-1945. Peter Lang Publishing, Bern and New York.

[53] O’Sullivan, C.J. (1988) Impressions on Irish and South African National Identity on Government Issued Postage Stamps. Éire-Ireland, 23, 104-115.

[54] Leith, A. (1971) Postage Stamps and Ideology in Communist China. Queen's Quarterly, 78, 176-186.

[55] Johnson, G. (2005) The Two Koreas' Societies Reflected in Stamps. East Asia, 22, 77-95. https://doi.org/10.1007/s12140-005-0010-x

[56] Kevane, M. (2008) Official Representations of the Nation: Comparing the Postage Stamps of Sudan and Burkina Faso. African Studies Quarterly, 10, 71-94.

[57] Slemrod, J.H. (2008) Why Is Elvis on Burkina Faso Postage Stamps? Cross-Country Evidence on the Commercialization of State Sovereignty. Journal of Empirical Legal Studies, 5, 683-712. https://doi.org/10.1111/j.1740-1461.2008.00138.x

[58] Brunn, S.D. (2011) Stamps as Messengers of Political Transition. Geographical Re- 
view, 101, 19-36. https://doi.org/10.1111/j.1931-0846.2011.00070.x

[59] Grant, J. (1995) The Socialist Construction of Philately in the Early Soviet Era. Comparative Studies in Society and History, 37, 476-493.

https://doi.org/10.1017/S0010417500019770

[60] Rowley, A. (2002) Miniature Propaganda: Self-Definition and Soviet Postage Stamps, 1917-41. Slavonica, 8, 135-157. https://doi.org/10.1179/sla.2002.8.2.135

[61] Rowell, D. (2010) A History of Russian Philately. www.rossica.org

[62] White, G.W. (1925) The Postage Stamps of the Soviet Union. Harris Publications, New York.

[63] McQueen, H. (1988) The Australian Stamp Image: Design and Ideology. Arena, 84, 78-96.

[64] Cusack, I. (2005) Tiny Transmitters of Nationalist and Colonial Ideology: The Postage Stamps of Portugal and Its Empire. Nations and Nationalism, 11, 581-612. https://doi.org/10.1111/j.1469-8129.2005.00221.x

[65] Easton, J. (1958) The De La Rue History of British and Foreign Postage Stamps, 1855-1901. Faber and Faber, London.

[66] Jones, R.A. (2001) Heroes of the Nation? The Celebration of Scientists on the Postage Stamps of Great Britain, France and West Germany. Journal of Contemporary History, 36, 403-422. https://doi.org/10.1177/002200940103600301

[67] Davidson, C. and Diamant, L. (1990) Stamping Our History. The Story of the United States Portrayed on Its Postage Stamps. American Heritage, 41, 109-110.

[68] Deans, P. and Dobson, P. (2005) Introduction: East Asian Postage Stamps as Socio-Political Artefacts. East Asia, 22, 3-7. https://doi.org/10.1007/s12140-005-0006-6

[69] Adedze, A. (2004) Commemorating the Chief: The Politics of Postage Stamps in West Africa. African Arts, 37, 68-96.https://doi.org/10.1162/afar.2004.37.2.68

[70] Brunn, S.D. (2002) Political Stamps of the Arab World: 1950-1999. In: Schofield, C., Newman, D. and Drysdale, A., Eds., The Razor's Edge: International Boundaries and Political Geography Essays in Honour of Professor Gerald Blake, Kluwer, The Hague, 77-105.

[71] Child, J. (2005) The Politics and Semiotics of the Smallest Icons of Popular Culture. Latin American Research Review, 40, 108-137. https://doi.org/10.1353/lar.2005.0003

[72] Child, J. (2009) Miniature Messages: The Semiotics and Politics of Latin American Postage Stamps. Duke University Press, Durham, NC. https://doi.org/10.1215/9780822389279

[73] Brunn, S.D. (2000) Stamps as Iconography: Celebrating the Independence of New European and Central Asian States. GeoJournal, 52, 315-323.

https://doi.org/10.1023/A:1014307914500

[74] Brunn, S.D. (2015) Visualizing Secularization through Changes in Religion Stamp Issues in Three Catholic European Countries. In: Brunn, S.D., Ed., The Changing World Religion Map: Sacred Places, Identities and Politics, Springer, Dordrecht, 2129-2144.

[75] Calver, M., Addison, K. and Annan, J. (2010) Postage Stamps as Teaching Aids in Biology. The American Biology Teacher, 73, 289-290. https://doi.org/10.1525/abt.2011.73.5.10

[76] Finlay, I. (1968) Postage Stamps and Modern Language Teaching. Modern Languages, 49, 119-121.

[77] Nuessel, F. (1996) Postage Stamps: A Pedagogical Tool in the Language Classroom. Mosaic. A Journal for Language Teachers, 3, 12-17. 
[78] Vigner, G. (1981) Le timbre-poste. La Françaisedans le Monde, 62, 876-877.

[79] Wood, R. (1980) Visible Language Policy-Bilingualism and Multilingualism on Postage Stamps. Visible Language, 14, 30-51.

[80] Wood, R.F. (1979) Teaching "Francophone" with Postage Stamps. Canadian Modern Language Review, 36, 105-124.

[81] Nuessel, F. and Cicagna, C. (1997) Postage Stamps as Pedagogical Instruments in the Italian Curriculum. Italica, 69, 210-227. https://doi.org/10.2307/479527

[82] Nuessel, F. (1984) Teaching Hispanic Culture with Postage Stamps. Canadian Modern Language Review, 40, 429-439.

[83] Kirman, J.M. and Jackson, C. (2000) The Use of Postage Stamps to Teach Social Studies Topics. Social Studies, 91, 187-190.

https://doi.org/10.1080/00377990009602464

[84] Newman, R.S. (1989) Orientalism for Kids: Postage Stamps and "Creating” South Asia. Journal of Developing Societies, 5, 70-82.

[85] Walker, R.S. (1969) Language on Stamps. Scott's Monthly Stamp Journal, 50, 289, 292-93. 301.

[86] Timothy, D.J. (2001) Postage Stamps, Microstates and Tourism. Tourism Recreation Research, 26, 85-88. https://doi.org/10.1080/02508281.2001.11081203

[87] Swan, G., Meade, T., Klein, D. and Serlon, D. (2006) Licking Disability: Reflections on the Politics of Postage Stamps. Radical History Review, 2006, 228-232. https://doi.org/10.1215/01636545-2006-94-228

[88] Hickey, M.G. and Kolterman, D.L. (2006) Special Women in My Life: Strategies for Writing Women into the Social Studies Curriculum. Social Education, 70, 190-196.

[89] Ogletree, S.M., Merritt, S. and Roberts, J. (1994) Female/Male Portrayals on U.S. Postage Stamps of the Twentieth Century. Communication Research Reports, 11, 77-85. https://doi.org/10.1080/08824099409359943

[90] Afshar, A. (2010) A Brief Iranian Medical History through Commemorative Postage Stamps. Archives of Iranian Medicine, 13, 161-165.

[91] Wood, M. (2010) The Horrible Gift of Freedom. Atlantic Slavery and the Representation-Emancipation. University of Georgia Press, Athens, GA.

[92] Stoetzer, C. (1953) Postage Stamps as Propaganda. Public Affairs Press, Washington DC.

[93] Davis, B. (1985) Maps on Postage Stamps as Propaganda. The Cartographic Journal, 22, 125-130. https://doi.org/10.1179/caj.1985.22.2.125

[94] Williams, L.N. and Williams, M. (1956) The Postage Stamp: Its History and Recognition. Penguin, London.

[95] DeYoung, G. (1986) Postage Stamps and the Popular Iconography of Science. The Journal of American Culture, 9, 1-14. https://doi.org/10.1111/j.1542-734X.1986.0903 1.X

[96] Jones, R.A. (2004) Science in National Cultures: The Message of Postage Stamps. Public Understanding of Science, 131, 75-81. https://doi.org/10.1177/0963662504042692

[97] Moffat, M.P. and Roth, S.G. (1950) Postage Stamps, Past and Present, as Avenues of Learning. The Journal of Educational Sociology, 24, 110-119. https://doi.org/10.2307/2263799

[98] Mukerji, C. and Schudson, M. (1991) Rethinking Popular Culture. University of California Press, Berkeley.

[99] Harrison, R.A., Holt, D. and Elton, R.J. (2002) Do Postage-Stamps Increase Re- 
sponse Rates to Postal Surveys? A Randomized Controlled Trial. International Journal of Epidemiology, 31, 872-874. https://doi.org/10.1093/ije/31.4.872

[100] Hensley, W.E. (1974) Increasing Response Rates by Choice of Postage Stamps. Public Opinion Quarterly, 38, 280-283. https://doi.org/10.1086/268160

[101] Cernada, C.P. (1988) Knowledge into Action. A Guide to Research Utilization. Bayward, Farmingdale, NY (postage stamps about health in Taiwan).

[102] Lefrère, J. and Danic, B. (2010) Transfusion, Blood Donation, and Postage Stamps: A Worldwide Review. Transfusion, 50, 1838-1848. https://doi.org/10.1111/j.1537-2995.2010.02671.x

[103] Yardley, C.B. (2014) The Representation of Science and Scientists on Postage Stamps. PhD Dissertation, Australian National University, Canberra. Australian Center for the Public Awareness of Science.

[104] Covington, K. and Brunn, S.D. (2006) Celebrating a Nation's Heritage on Music Stamps: Constructing an International Community. GeoJournal, 65, 125-135. https://doi.org/10.1007/s10708-006-0015-Z

[105] Pinto, G. (2007) A Postage Stamp about the Periodic Table. Journal of Chemical Education, 84, 1919. https://doi.org/10.1021/ed084p1919

[106] Schrecky, J.O. (1989) Organic Chemistry on Postage Stamps. Journal of Chemical Education, 66, 624. https://doi.org/10.1021/ed066p624

[107] Puntanen, S. and Styan, G.P.H. (2013) Stochastic Stamp: A Philatelic Introduction to Chance. Chance, 21, 36-41. https://doi.org/10.1080/09332480.2008.10722916

[108] Styan, G.P.H. and Trenklen, G. (2007) A Philatelic Excursion with Jeff Hunter in Probability and Matrix Theory. Journal of Applied Mathematics and Decision Science, 2007, Article ID: 13749. https://doi.org/10.1155/2007/13749

[109] Rugendorff, E.W. and Wilson, T. (1997) The History of Urology on Postage Stamps and Cancellations. The Journal of Urology, 158, 1135-1139. https://doi.org/10.1016/S0022-5347(01)64209-5

[110] Habashi, F. (1979) Mining and Metallurgy on Postage Stamps. Metallurgical Extractive, Quebec City.

[111] Nemésio, A, Serxes, D. and Vasconcelos, H. (2013) The Public Perception of Animal Diversity: What Do Postage Stamps Tell Us? Frontiers in Ecology and the Environment, 11, 9-10. https://doi.org/10.1890/13.WB.001

[112] Pruess, K.P. (2015) Postage Stamps Showing Bees and Hives. Bee World, 54, 53-56. https://doi.org/10.1080/0005772X.1973.11097454

[113] Anderson, B. (1991) Imagined Communities: Reflections on the Origins and Spread of Nationalism. Verso, London.

[114] Billig, M. (1998) Banal Nationalism. Sage, London.

[115] Flusty, S., Dittmer, J., Gilbert, E. and Kuus, M. (2008) Interventions in Banal Neoimperialism. Political Geography, 27, 617-629.

[116] Brunn, S.D. (2015) Philatelic Boosterism: Tourism Stamps of Small Island States. International Journal of Responsible Tourism, 4, 23-52.

[117] Scott's Postage Stamp Catalogue (2015) Amos Publications, Sydney, OH.

[118] Giannopoulos, P. (Accessed 11 April 2016) Website Illustrates Stamps of Global Warming.

[119] Hillger, D. (Accessed 11 April 2016) Website for Philatelic Materials Related to Global Warming and Climate Change.

[120] Toth, G. and Hillger, D. (2013) A Philatelic History of Climate Change. Weather- 
wise, 66, 34-39. https://doi.org/10.1080/00431672.2013.800420

[121] Brunn, S.D. (1984) Future of the Nation State System. In: Taylor, P.J. and House, J., Eds., Political Geography. Recent Advances and Directions, Wiley, London and Chichester, 131-156.

[122] Brunn, S.D. (2013) Geographies in 2050. Progress in Geography, 32, 1006-1017.

[123] Brunn, S.D. (Forthcoming) Using United Nations Stamps to Obtain a Reading on the State of the World. In: Brunn, S.D., Ed., The Changing World Language Map.

Submit or recommend next manuscript to SCIRP and we will provide best service for you:

Accepting pre-submission inquiries through Email, Facebook, LinkedIn, Twitter, etc. A wide selection of journals (inclusive of 9 subjects, more than 200 journals)

Providing 24-hour high-quality service

User-friendly online submission system

Fair and swift peer-review system

Efficient typesetting and proofreading procedure

Display of the result of downloads and visits, as well as the number of cited articles Maximum dissemination of your research work

Submit your manuscript at: http://papersubmission.scirp.org/

Or contactnr@scirp.org 